\section{BEGININGS OF NEUROSURGERY AT THE UNIVERSITY OF IBADAN, NIGERIA}

\section{BY}

\author{
E. LATUNDE ODEKU, M. D. (HOWARD), \\ F.A.C.S
}

Neurosurgery Unit, University of Ibadan, Nigeria

\section{Introduction}

Available data concerning various neurologic disease entities occurring in West African are still appalling scanty, such that a vigorous effort seems urgently essential in the next few years to rectify this lag. In various parts of Nigeria, like much elsewhere in Africa, much neurologic problems presently remain inadvertently neglected for the more pressing consideration of the common tropical diseases and general surgical emergencies. It can be safely presumed that every day there are innumerable illnesses of the nervous system, unrecognized and untreated, that go down in these parts with many a patient, hidden in the remote villages or lost forever irretrievably into the many unmarked graves.

The work of Monekosso on the endemic tropic myelopathies in Nigeria is familiar to West African medical readers. The transactions of Collomb et al. in Dakar on entities such as intracranial tumours, vascular malformations and abscesses in Africans are well commendable. In a recent brief study of "The Pattern of Neurological Disease in Ibadan" published by KAUSHIK (1961), another noteworthy beginning has been made in a useful direction. It is hoped that these landmark efforts will, by the paucity made apparent thereby, serve to provoke more clinicians in these areas into a determined effort of bringing verified nerulogic diseases of all types into light.

The purpose of this communication is to introduce the presence of Neurological Surgery as a defined discipline to Nigeria and to the West African Medical scene.

\section{Prelude to Neurosurgery}

Progress in development at the University of Ibadan on a new subspeciality in October, 1962 when the Rockefeller Foundation of New York sponsored an academic facility for a neurosurgeon in the Faculty of Medicine. This possibility stemmed from the dynamic programmed of the Vice-Chancellor, Dr. Kenneth Dike and from the vigilant outlook of the new Dean of the Medical School, Professor J. C. Edozien. An interview with Dr. John M. Weir of Rockefeller Foundation in New York City in August, 1962 lent a good deal of impetus to the author's keen intent on a Neurosurgical Unit in Nigeria. By the end of October 1962 this new unit made a start at the University College Hospital, Ibadan with 8 kids.

Neurosurgical Activities, University of Ibadan - Before October, 1962.
It is a foregone assumption that for a newcomer the task of seeking foundation in the past for some local guidance would arise immediately. Unfortunately, records of activities during the early 1950's at Adeoyo Hospital, Ibadan could not be gathered reliably. The Operating Theatre List and Surgical Files available at University College Hospital, Ibadan alone therefore provided this needed outlet. A detailed search of the records showed a total of 25,167 surgical procedures of all categories and magnitudes from July 30, 1956 to October 24, 1962. They represent obstetrics and gynaecology, general surgery (including urologic, thoracic, plastic and neurosurgical items) and also ophthalmic and otorhinolaryngologic cases which were already set aside as sub-departments of general surgery. Of this grand total of over 25,000 operations 421 or 1.67 per cent fall in the broad general realm of neurosurgery, yielding an average of about 67 per annum in the 6 year 3 month period under consideration. Forty-eight of these procedures are relegated to the category of what might be termed "surface neurosurgery" or minor surgery of scalp lesions. They consist of traumatic scalp lacerations, cysts and other extracranial lesions (cutaneous aneurismal formation, neurofibroma, lipomas, abscesses etc.). The remaining 373 cases (see Appendix 1) average 60 per year and constitute 1.48 per cent of the grand total of the surgery performed. Of special interest is the tuberculous spine with varying degrees of neurologic deficts, from subjective pain to obvious weakness of the extremeties. These have been quite ably handled by KONSTAM (1962). He has dealt exhaustively with the problem in a mixed consevative ambulant and surgical decompression (usually costotransversectomy or occasional anterolateral decompression) in the period now being examined. Presently these patients are the responsibility of the Orthopaedics division and are, for departmental convenience, still being cared for in the Spinal Tuberculosis Clinic. The bulk of the neurosurgical work consisted of the treatment of tuberculous spine with deficient spinal cord function, traumatic head injuries and repair of congenital myelomeningocoeles. Relatively few essential diagnostic steps (carotid arteriography, air studies) were taken. Myelography was employed more freely. From Appendix I it can be seen that there is a place for neurosurgical specialists in Nigeria and that this specialty like a number of others cannot be considered a luxury. This preliminary report now proposes to examine the accomplishments of the new Neurosurgical Unit at Ibadan from October 1962 to October 1963, its failure and its possibilities, its contributions and its needs, its trials, its inevitable presence, its hopes, its ideals and its needed place in the daily lives of Nigerians today and tomorrow.

\section{Neurosurgery, University of Ibadan - from October 1962 to October 1963}

The first month, October 1962, was spent in making preliminary arrangements. Only 3 patients were seen in consultation, and only 2 operations performed, the first being on October 25, 1962. in November and 
December 1962 the average weekly clinic attendance was 4 to 5; by March 1963 it was 10, and by June 1963 an average of 18 to 22 (including 4 to 6 or more new patients) had been reached. In October 1963, 28 patients were seen in one clinic session the attendance being checked by the fact that the clinic day is held down to once a week for a 4-5 hour period. This limitation prevents the situation from becoming chaotic and unmanageable since a major share of the consultations received come from the patient load already admitted to the hospital in the various other services. The weekly Neurosurgery clinic attendance accounts for 30 per cent, if all consultations received. Av average in-patient number of $18-20$ is kept on the neurosurgery service, the highest thus far being 29 . Neurodioagnostic studies range from 5-10 per week, with many neurologic patients requiring both arteriography and pneumoencephalography for clearance since useful baseline adjuncts, such as EEG, are not yet available. The need for an EMG equipment is also acute due to a high number of spinal cord deficient patients encountered from auto-accidents, from domestic injuries and the professional palm-wine tapper's paraplegia.

\section{A. ACCOMPLISHMENTS AND CONTRIBUTIONS}

During $11^{1} / 2$ months 206 diagnostic procedures were carried out (Table 1) andn 134 operations were

Table I. 206 Neuroradiologic Studies. performed (Appendix 3). A total of 361 new consultants requests

Were received and answered (Appendix 2). It shows the range of problems presented in the first year of the unit's existence

\section{(i) Neurodiagnostic Studies}

In occupation with the Radiology Department (under Professor Cockshott) very adequate diagnostic studies were readily obtained whenever needed. In addition to the table contents below, numerous ventricular subarachnoid space taps and Blackfan dye tests were performed in infants with various congenital malformations as a part of pre- and post-operative evaluation.

In the above series of studies the ventriculograms and myelograms in particular yielded a high proportion of useful positive findings. Only 2 significant complications occurred. During a cisternal puncture for myelography a 45 year old man with paraplegia suddenly lapsed into apnea, hypotension and coma. He was revived within a few minutes with vigorous supportive measures. Subsequently the study was successfully repeated. A second complication resulted in left hemiplegia, central facial paralysis and dysphasia in the process of bilateral cerebral arteriography in a 31 year old man with headaches and papilloedema following a head injury. Two months later the facial paralysis and dysphasia had completely resolved and

\begin{tabular}{|c|c|c|c|c|}
\hline Study & Route employed & $\begin{array}{c}\text { No. } \\
\text { performed }\end{array}$ & $\begin{array}{l}\text { Total No. } \\
\text { of studies }\end{array}$ & Complications \\
\hline Myelography & $\begin{array}{l}\text { (a) Lumbar puncture } \\
\text { (b) Cisternal Puncture } \\
\text { (c) Combination (LP \& } \\
\text { CP) }\end{array}$ & $\begin{array}{r}33 \\
5 \\
\\
2\end{array}$ & 40 & 1 \\
\hline Intracranial Arteriography & $\begin{array}{l}\text { (a) Unilateral carotid } \\
\text { (b) Bilateral carotid } \\
\text { (c) Vertebral (Seldinger } \\
\text { Femoral } \\
\text { Catheterisation) }\end{array}$ & $\begin{array}{r}35 \\
44 \\
5\end{array}$ & 84 & 1 \\
\hline Pneumoencephalography & $\begin{array}{l}\text { (a) Lumbar Puncture } \\
\text { (b) Cisternal Puncture }\end{array}$ & $\begin{array}{r}34 \\
4\end{array}$ & 38 & None \\
\hline Vetriculography & $\begin{array}{l}\text { (a) Percutaneous } \\
\text { (Anterior Fon tanel) } \\
\text { (b) Trephination } \\
\text { (c) Twist drill }\end{array}$ & $\begin{array}{r}32 \\
11 \\
1\end{array}$ & $\begin{array}{c}44 \\
\text { (including } 1 \\
\text { myodil } \\
\text { vetric. } \\
\text { Study) }\end{array}$ & None \\
\hline
\end{tabular}


only a 20 per cent, residual left hemiparesis was still evident.

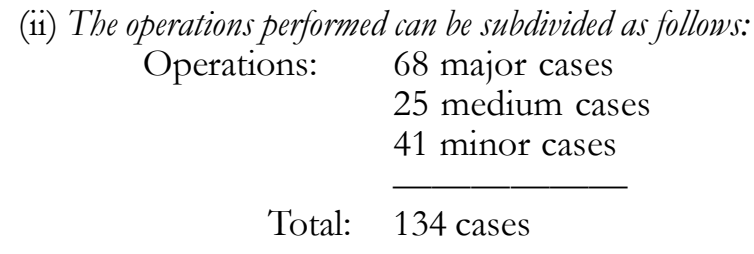

There were the inevitable difficulties in setting up a new unit, but much encouragement came from the high-quality neuroradiographs in view, the anaesthetist's patience, and adequate supply of blood from the blood bank. The theatre nurse coped adequately and contributed greatly to successes achieved. The author also pays tribute, with the utmost regard, to the sick African who comes from the various parts of Nigeria, Ghana, the Cameroons and from the indispensable cooperation of the departments of Paediatrics, Medicine and General Surgery of the University College Hospital, Ibadan.

Cordotomy for pain, aneurismal intracranial surgery and herniated disk problems are conspicuously absent. Except for 6 minor cases by the junior house officer and 2 trauma laminectomies jointly with Mr. Richard (Orthopaedics), all of these procedures were performed by one neurosurgeon.

(iii) Perhaps the singular contribution of the Neurosurgey unit in these early months centers in broadening the horizons of the medical students and the training of the recent graduate doctors. It brings the surgical house officer into a more organized approach to the management of the common encounters such as head injuries or the paralyzed patients. By its presence, it alerts everyone into being more immediately aware of the acute meaning of key neurologic deficts, and to indicate gradually that lesions of the nervous system per se, contrary to uniformed opinions and beliefs, are not always synonymous with utter hopelessness.

\section{B. FAILURE}

A deeper look into this report leads inevitably into an enquiry of the shortcomings of the achievements tabled below, for a more comprehensive appraisal. The process of triage, with all its inherent undesirable implications, compromises the surgeon's attention and care of some complicated but deserving patients in preference to the more salvageable, though not necessarily easier to deal with. Not altogether satisfactory, these compromises are too often imperative and all-out-effort is, by sheer circumstance, frequently made impossible. The greatest factor ion "failures" is the acute shortage of hospital beds which is a universal cry throughout the various divisions. Relatively simple neurologic diseases seen early in the outpatients lapse into the inoperable by the time admission or operating time could be secured. This is in the peculiar nature of neurologic problems: the once readily accessible brain tumour forcibly "neglected" by having to wait, turns up at las on the ward corridors, breathlessly beyond the realm of useful surgery.

More glaring among the failures are the postoperative complications ( $7 \%$ infection) and the mortality of $10.4 \%$ incurred. There is also the high rate of decubitus ulceration as shown hereunder in paraplegics, a reflection of still inadequate indoctrination of the burdened nursing staff.

\section{OUTLOOK FOR NEUROSUGERY IN NIGERIA}

The needs of Neurosurgery here at Ibadan are manifold and countrywide in effect. Most of these are intimately connected with its present growing pains. Briefly, among these are

1) expedition of hospital patient turnover by establishment of convalescent homes are rehabilitation centers, and an improved communication system with the patient's relations.

2) Adequate follow-up facilities for continued patientcare through more medical social (Almoner) services and effective direct responsibility of the local physician in a joint welfare programme of management for the neurologically incapacitated patient.

3) The organization of an integrated Neurosurgery Residency training Curriculum in a postgraduate School of Medicine at the University of Ibadan. This training team will serve to implement the objective of defining surgical neurologic problems as they arise locally in Nigeria, which should premise a programme of research on these problems. The primary aim of research is to enable us to know more, but in this context to know more in a useful way. This is essential in a situation where the acquisition of knowledge solely for its own sake is already overshadowed by enormous task of the care of prevalent common tropical diseases.

4) Building up liaison service schemes for neurosurgical emergencies and the care of the acute patient at strategically located hospitals throughout Nigeria.

5) Emphasis on Paediatric Neurosurgery through a National Foundation, wholeheartedly devoted to diseases of the nervous system in children, congenital and acquired.

6) Evolvement of a Neurologic Institute corodinated by various university and other medical centres in Nigeria. This composite centre will embrace within its walls, (all in one great correlation of practical knowledge and approach), the structural basis of neuroanatomy, the functional understanding of neurophysiology and neurochemistry, the clarifying depths of neuropathology and all essences of neurology and psychiatry, the appliances of physical medicine and dynamic tools of neurosurgery. 


\section{Summary and Conclusions}

1. The fact is presented that a Neurosurgical Unit exists at the University of Ibadan and the University College Hospital, Ibadan, Nigeria, West Africa.

2. A board analysis of its first year of operation has been made, showing its efforts and its failures; its trials, its tribulations its intellectual danger of a oneman show; its lesions and its hopes. Whatever faults and failings this year old unit may have project beyond this simple analysis for a better background of local experience, hopefully against tomorrow and for many other Nigerian workers who, into this field, will come.

3. The existence of this Neurosurgery unit shows, once again, that while great expense and resources may be essential for an established medical facility a humble but reasonable beginning can be made in any needed sphere of Medicine. Given the arid conditions of necessity and some opportunity, much can be readily accomplished with much less by a stretch of determined effort and a sense of purpose.

4. it is here suggested that the idea, that medical subspecialities in the technically under-developed independent African countries are a luxury only of the future, denies the essence of progress in a broad perspective. The need, the great need for specialized medical attention, is already there. The presence of the specialist only serves to make it glaringly obvious.

5. various difficulties of the Neurosurgery Unit at Ibadan are by no means confined to its beginning and will undoubtedly continue and grow into the years ahead. Perhaps therein lies the saving grace, in the vivid knowledge that "the price of progress is trouble." The statement is credited to Foster Kennedy that "He who care patients suffering from brain tumour must ring to his problem much thought and stout action. There is need also of a formidable optimism for the dice of the gods are loaded." In this twilight of new nationhood and pressing readjustments of social environment, for brain tumours as well as many a neurosurgical entity (which could nowadays be handeled routinely elsewhere) the dice of the gods here in West Africa are doubly loaded.

\section{References}

KAUSHIK, S. C. (1961). "The Pattern of Neurological Disease in Ibadan," First Pan-African Psychiatric Conference, Abeokuta, Nigeria. (Edited by T. A. Lambo), p. 78.

KONSTAN, P. G. \& BLESOVSKY, A. (1962). The Ambulant Treatment of Spinal Tuberculosis. Brit. J. Surg., 50, 26.

A P P E N D IX 1. Categories of O perations Perform ed

\begin{tabular}{|c|c|c|c|}
\hline Procedure perform ed & D iagnos is & $\begin{array}{l}\mathrm{N} 0 \text {. of } \\
\text { c a s e s }\end{array}$ & 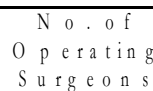 \\
\hline $\begin{array}{l}\text { D ebridement, T rephination, } \\
\text { Subtemporal, Decompression }\end{array}$ & $\begin{array}{l}\text { Craniocerebraltrauma (depressed } \\
\text { skull fracture }\end{array}$ & 77 & 22 \\
\hline Treph in ation & $\begin{array}{l}\text { Subdural Haematoma } \\
\text { E pid ural Haematoma } \\
\text { Leptomentigitisand C erebral } \\
\text { A b scess (drainage) } \\
\text { S ubdural A bscess H ydrocephalic } \\
\text { S n d dom }\end{array}$ & $\begin{array}{l}7 \\
1 \\
19 \\
3 \\
3\end{array}$ & 9 \\
\hline $\begin{array}{l}\text { C raniotom y (o rbital } \\
\text { decompresolio n) }\end{array}$ & $\begin{array}{l}\text { Exophthalmos } \\
\text { O rbitalroofoesteoma } \\
\text { Retro-orbital T umour } \\
\text { (No histologyarailable } \\
\text { Chronic Subdural Haematom a } \\
\text { Encephalomalacia } \\
\text { Frontal Tuberculosis } \\
\text { Pseudoporencephaly } \\
\text { Cerebellar A strocytom a } \\
\text { Sarcoma (? M en ingeal) } \\
\text { O steom yelitis and E pidural } \\
\text { A bscess } \\
\text { Frontal M ucocoele } \\
\text { O c cipital Encephalocoele } \\
\text { Frontal Encephalocoele }\end{array}$ & $\begin{array}{l}1 \\
1 \\
1 \\
1 \\
1 \\
1 \\
1 \\
1 \\
1 \\
12 \\
6 \\
2 \\
1\end{array}$ & 11 \\
\hline $\begin{array}{l}\text { Fac ial Nerve D ecom pression } \\
\text { H olter Valve V.J.C. Shunt }\end{array}$ & $\begin{array}{l}\text { Facial Nerve Palsy } \\
\text { (? R a m say-H unt Syndrome } \\
\text { Hydrocephalic syndrom e }\end{array}$ & 9 & $\begin{array}{l}1 \\
3\end{array}$ \\
\hline $\begin{array}{l}\text { Excision and Repair } \\
\text { Excision }\end{array}$ & $\begin{array}{l}\text { M e ningom yelecoele and } \\
\text { m yelom eningocoele } \\
\text { Sacrococcygealcycts (teratomas, } \\
\text { dermoids) }\end{array}$ & $\begin{array}{l}33 \\
6\end{array}$ & 6 \\
\hline $\mathrm{Skull} \mathrm{Traction}$ & Cervical Spine Fracture-d is location & 17 & \\
\hline
\end{tabular}


Appendix 1 - contd

\begin{tabular}{|c|c|c|c|}
\hline Procedure performed & Diagnosis & $\begin{array}{l}\text { No. of } \\
\text { cases }\end{array}$ & $\begin{array}{c}\text { No. of } \\
\text { Operating } \\
\text { Surgeon }\end{array}$ \\
\hline Laminectomy & $\begin{array}{l}\text { Lumber Facture dislocation } \\
\text { “Spinal Neurofiobroma” Epidural } \\
\text { Lymphosarcoma } \\
\text { Epidural Metastatic Thyroid } \\
\text { Carcinoma } \\
\text { Epidural Metastatic } \\
\text { anaplastic carcinoma } \\
\text { Transverse Myelitis } \\
\text { (aetiology undetermined) } \\
\text { Haemangioma } \\
\text { Histoplasmosis } \\
\text { Segmental Arachnoiditis } \\
\text { Herniated IV disk } \\
\text { Staphylococal Spondylitis (biopsy) } \\
\text { “Cervical Neoplasm” (type } \\
\text { undetermined) } \\
\text { Diagnosis not available }\end{array}$ & $\begin{array}{l}3 \\
1 \\
2 \\
1 \\
1 \\
1 \\
1 \\
1 \\
1 \\
1 \\
1 \\
1 \\
1 \\
1\end{array}$ & 14 \\
\hline $\begin{array}{l}\text { Laminectomy } \\
\text { Costotranversectomy } \\
\text { Anterolateral Decompression }\end{array}$ & $\begin{array}{l}\text { Spinal Tuberculosis } \\
\text { (paraparesis or paraplegia) }\end{array}$ & $\begin{array}{r}2 \\
113 \\
9 \\
\end{array}$ & \\
\hline $\begin{array}{l}\text { Supradiaphgramatic } \\
\text { Sympathctomy }\end{array}$ & Essential Hypertension & 3 & 2 \\
\hline $\begin{array}{l}\text { Miscellaneous } \\
\text { Skull biopsy }\end{array}$ & $\begin{array}{l}\text { Metastatic Hypernephroma } \\
\text { Metatstatic Thyroid } \\
\text { Adenocarcinoma } \\
\text { Fibrous Dysplasia }\end{array}$ & $\begin{array}{l}1 \\
1 \\
1\end{array}$ & \\
\hline Excision & Plexiform Neurofibroma & 4 & 14 \\
\hline Removal of Holter Valve & $\begin{array}{l}\text { Malfunctioning V.J.C. Shunt } \\
\text { (Hyrocephalus) }\end{array}$ & 2 & \\
\hline Carpal Tunnel release & $\begin{array}{l}\text { Median Nerve Compression } \\
\text { Neuropathy }\end{array}$ & 1 & \\
\hline
\end{tabular}


Appendix $1-$ cont'd $^{\prime}$

\begin{tabular}{|c|c|c|c|}
\hline Procedure performed & Diagnosis & $\begin{array}{l}\text { No. of } \\
\text { cases }\end{array}$ & $\begin{array}{l}\text { No. of } \\
\text { Operating } \\
\text { Surgeon }\end{array}$ \\
\hline Neurolysis & Radial Nerve Palsy & 2 & \\
\hline Transposition of Ulna Nerve & Tardy Ulnar Neuritis & 1 & \\
\hline Neurorrhaphy & Neurotmesis (Ulnar, Median Nerves) & 5 & \\
\hline Nerve Biopsy & $\begin{array}{l}\text { Tuberculoid Leprosy (Radial Nerve) } \\
\text { Glomus Caroticum }\end{array}$ & 1 & \\
\hline Excision & $\begin{array}{l}\text { "Inconclusive" Cerebral } \\
\text { Arteriography }\end{array}$ & 1 & \\
\hline $\begin{array}{l}\text { Cutdown exposure of carotid } \\
\text { artery }\end{array}$ & & 1 & \\
\hline
\end{tabular}

Appendix 2. Categories of Clincal Entities Encountered

(a) Congenital

Infantile hydrocephalic syndrome

(including a Dandy-Walker syndrome and one associated with osteogenesis imperfects)

menigoencephalocoele (occipital 8)

(nasofrontal 3)

spinal dysraphism (myelomeningocoele

(meningomyecoele

8)

craniosynostosis

micrencephaly

(b) Traumatic

Craniocerebral trauma (all types)

Chronic subdural haematoma

Spinal trauma (fracture-dislocation (cervical8)

$\begin{array}{ll}\text { (dorsal } & 4 \\ \text { (dorsolumbar } & 1) \\ \text { (lumbar } & 7 \text { ) } \\ \text { (sacral } & 1)\end{array}$

(including central spinal cord syndrome, transverse myelopathy, conus-epiconus medullaris syndrome, cauda equina syndrome)

Erb-Duchenne palsy (birth)

"Charcot's Joint" (brachial plexus trauma)

ulnar, median or radial palsy (Neurotmesis)

femoral nerve "injection" neuropathy 
Appendix 2. - cont'd

(c) Infectious

Cerebral abscess (pyogenic)

Cerebral tuberculoma

Cerebral tuberculoma (suspect)

Intracranial phycomycosis

Complicated leptomeningitis

(pyogenic

5)

(tuberculous

1)

(subdural effucion

4)

postmeningitic hydrocephalus

frontal osteomyelitis (pyogenic)

basilar osteomyelitis (tuberculous)

spinal epidural abscess (pyogenic)

tuberculous spondylitis (transverse myelopathy)

spina bifida occulta with epispinal abscess (pyogenic)

tuberculoid leprosy peripheral neuropathy

modified tetanus

tabes dorsalis

second ary syringomyelia (arachnoiditis)

(d) Neoplastic (and non-plastic tumours)

* cerebral glioblas toma mutiforme

$4^{\text {th }}$ ventricle ependymoblastoma

pontine glioma

vermis medulloblastoma

cerebellar astrocytoma

suprasellar retinoblas to ma

intracranial teratoma

orbitotemporal meningosarcome (with metastases)

bifrontal convexity meningioma

coexisting meningiomata - neurilemmomata

fibrous dysplasia (non-neoplastic) (orbitofrontal 2) 
Appendix 2. cont'd

in tracranial Burkitt's neoplasm

frontal mucocoele

sphenoidal ridge meningioma (suspect)

coexisting glomus jugulate and caroticum

in tramed ullary "cyst" (aetiology unknown)

in tradural extramed ullary neuro fibroma

von Recklinghausen's disease (peripheral)

lu mbosacral plexiform neuro fibroma

(* 1 in a 60 year old man of non-African origin)

Intraspinal giant schwannoma

(Burkitt's neoplasm

Spinal epidural (reticulum cell sarcoma

epispimal cervical lipoma

(e) Vascular

intracranial an eurysm

"vertebral artery compression tetraplegia" (cervical spondylosis)

cavernous sinus thrombosis

retinal venous thrombosis

unexplained "subarachnoid haemorrhage"

(c erebral thrombosis

Cerebrovascular acciden ts

Cerebral thrombophlebitis (suspect)

(f) Degenerative

chronic lateral sclerosis (cord) syndrome

disseminated sclerosis (suspect)

fron to-ponto-cerebellar atrophy (suspect) 
Appendix 2. cont'd

(g) Problem Pain

migraine hemicranias

unexplained cephalalgia

occipital neuralgia

tic douloureux

carpal tunnel compression (median nerve) neuropathy

"low back pain syndrome" (hypertrophic spondylitis

(h) Mescellaneous

"convulsive disorders" (all types) (post-traumatic

Parkinsonism

post infectious encephalitis

“pseudoporencephaly"

"encephalopathy"

(toxic

(post cardiac arrest

(hepatic

acute cerebellar ataxia (childhood)

Hand-Schuller-Christian syndrome

Libman-Sacks syndrome (lupus erythromatosis)

"postpartum monoparesis"

unexplained cauda-equina syndrome

unexplained Brown-Sequeard syndrome

unexplained transverse myelopathy

miscellaneous non-neurologic lesions (scalplesions, etc.)

functional "supratentorial" disorder 
Appendix 3. General Categories of Operations Performed

\begin{tabular}{|c|c|}
\hline 6 craniectomies and craniotomies & major craniocerebral trauma \\
\hline 3 osteoplastic cranio to mies and craniectomy & cerebral abscess \\
\hline 1 osteoplastic cranio to my (Hypophysectomy) & metastatic breast carcinoma \\
\hline 1 osteoplastic cranio to my & cerebral tuberculoma \\
\hline 2 craniectomy and osteoplastic craniotomy & fibrous dysplasia (orbito-frontal) \\
\hline $\begin{array}{l}11 \text { osteoplastic craniotomies } \\
\text { suboccipital craniectomies }\end{array}$ & $\begin{array}{l}\text { neoplasm (cere bellar as trocytoma, } \\
\text { vermis medulloblastoma, teratoma, } \\
\text { aneurismal bone cyst, } \\
\text { retinoblastoma, meningioma, } \\
\text { Burkitt's tumour) }\end{array}$ \\
\hline 2 craniectomies & craniosynostosis \\
\hline 5 laminectomies & $\begin{array}{l}\text { spinal trauma (partial transverse } \\
\text { myelopathy, cauda equine and } \\
\text { conus-epiconus medullaris } \\
\text { syndromes, etc.) }\end{array}$ \\
\hline 1 laminectomy & $\begin{array}{l}\text { epidural abscess (staphylococcus } \\
\text { pyogenes) }\end{array}$ \\
\hline 8 laminectomies & $\begin{array}{l}\text { neoplasm (reticulum cell sarcoma, } \\
\text { Burkitt's tumour, neuroblastoma, } \\
\text { giant schwannoma, neurofibroma, } \\
\text { fibrolipoma) }\end{array}$ \\
\hline 9 laminectomies & $\begin{array}{l}\text { miscellane ous (intramedullary cysts, } \\
\text { chronic lateral sclerosis syndrome, } \\
\text { adhesive arachnoiditis - } \\
\text { syringomyelia, etc.) }\end{array}$ \\
\hline 7 plastic repairs of meningoencephalocoeles & $\begin{array}{l}\text { (1 lumbar } \\
\text { (5 lumbosacral } \\
\text { (1 sacral }\end{array}$ \\
\hline 8 plastic repairs of meningoencephalocoeles & $\begin{array}{l}\text { (6 occipital } \\
(2 \text { naso frontal }\end{array}$ \\
\hline 10 ven triculo-caval Holter valve shunts & $\begin{array}{l}\text { (for infantile hydrocephalus (congenital and post } \\
\text { meningitic) }\end{array}$ \\
\hline 10 venticulo-peritoneal Holter valve shunts & \\
\hline 2 retrogass erian rhizotomies & tic douloureux \\
\hline 7 miscellan eous medium procedures & $\begin{array}{l}\text { cervical epispinal lipoma, excision } \\
\text { of post-traumatic cortical scar etc. }\end{array}$ \\
\hline 41 miscellaneous minor procedures & $\begin{array}{l}\text { trephinations for ventriculography, } \\
\text { tapping of cerebral abscess, } \\
\text { neoplastic cysts, etc., carpal tunnel } \\
\text { release, occipital neurectomy, piano- } \\
\text { wire Hoen skull traction, Crutchfield } \\
\text { tongs application, bone-button skull } \\
\text { biopsies, Holter-valve shunt } \\
\text { revisions, etc. }\end{array}$ \\
\hline
\end{tabular}

